\section{IJ§ER}

ISSN: 2149-5939
International Journal of Social Sciences and Education Research

Online, http://dergipark.gov.tr/ijsser

Volume: 1(2), 2015

\title{
Matematik öğretmen adaylarının problem çözmede öz değerlendirme- leri ve problem çözmeye yönelik önerileri
}

\section{Pre-service mathematics teachers' self-evaluation in mathematics related-problem solving and their solutions}

\author{
Ümit Kul1 Sedef Çelik²
}

\begin{abstract}
Received Date: $01 / 02$ / 2015
Accepted Date: 01 / 04 / 2015

$\ddot{O} z$

Bu araştırma ortaokul matematik öğretmen adaylarının, problem çözmede yaptıkları hataları ve eksiklikleri fark edip bu duruma ilişkin çözüm önerileri bulunması amacıyla yapılmıştır. Çalışma nitel araştırma yöntemlerinden durum çalışması deseninde tasarlamıştır. Çalı̧̧ma grubunu ise 2014- 2015 eğitim öğretim yılında Artvin Çoruh Üniversitesi Ĕ̆itim Fakültesi İlköğretim Matematik Öğretimi programında öğrenim gören 1. Sinıf ortaokul matematik öğretmen adaylarından oluşmaktadır. Çalışmanın veri toplama aracı olarak araştırmacılar tarafindan geliştirilen 6 soruluk görüşme formu tasarlanmıştır. Elde edilen verilerin nitel analizi sonucunda katılımcılar soru çözümünde yaptıkları hata ve eksikliklerin genel olarak kişisel ve çevresel nedenlere bağlı olduğunu dile getirmişlerdir. Kişisel nedenlerin çevresel nedenlerden daha çok olduğu saptanmıştır. Katılımcıların problem çözmede kendilerini değerlendirirken karşılaştı̆̆ kişisel nedenler psikolojik durum, konu alanı eksikliği ve işlem becerileriyle ilgili iken çevresel nedenler kurumsal ve diğer nedenler olarak sinıflandırılmıştır. İlgili alanda yapılabilecek diğer çalışmalar için araştırmacılara bazı önerilerde bulunulmuştur.
\end{abstract}

Anahtar sözcükler: Matematik ögretmen adayları, öz değerlendirme, hata yaklaşımı

\begin{abstract}
This study was conducted in an effort to identify primary school pre-service mathematics teachers' errors and deficiencies in dealing with mathematics-related problem solving and to offer solutions and recommendations pertaining to this issue. Case study approach which is the one of the qualitative research methods was used in this study. To achieve the above aim, in the 2014-2015 academic year, this study consists of first year pre-service mathematics teachers who are enrolled in Artvin Çoruh University Education Faculty of Mathematics Education Department. An open-ended question form including six questions was developed by the researchers of the study in order to collect required data. According to participants' accounts, their errors and deficiencies in dealing with problem solving process that could be classified as having both personal and environmental issues was revealed through the qualitative analysis of the data. It was determined that personal issues are more effective than environmental issues. This study classified the reasons behind participants' mistakes and deficiencies in dealing with mathematics-related problem solving as an either personal issues which are mainly related to psychological, lack of content knowledge and operational skills, and environmental issues which are related to institutional and other. This study presented some recommendations for the researchers who will study on this relevant field.
\end{abstract}

Keywords: Pre-service mathematics teachers, self-evaluation, error approach

\section{Giriş}

Matematik eğitimi araştırmaları matematiksel düşünmeyi ve matematiksel bilginin doğasını tanımlamayı amaç edinmiştir. Öğrencilerin düşünce süreçlerinin belirlenmesi, matematik eğitimi ve öğretim uygulamalarının düzenlenmesine yardım edebilir. Ayrıca problem çözme sırasında

\footnotetext{
${ }^{1}$ Assist. Prof. Dr., Faculty of Education, Artvin Çoruh University, ARTVIN/TURKEY, umitkul@artvin.edu.tr

${ }^{2}$ Research Assistant, Faculty of Education, Artvin Çoruh University, ARTVIN/TURKEY, sedefcelik@artvin.edu.tr
} 
Kul, Ü., Çelik, S. (2015). Matematik öğretmen adaylarının problem çözmede öz değerlendirmeleri ve problem çözmeye yönelik önerileri. International Journal of Social Sciences and Education Research, 1 (2), 399-410.

öğrencilerin yaptıkları hatalar ve yanılgılar onların matematiksel bilgi ve becerileri hakkında ipuçları verebilir (Karataş ve Güven, 2003). Kavram yanılgısının bir sonucu olan hata, matematiksel ifadelerin ve fikirlerin yanlış kullanılması ve sonuçlandırılmasıdır (Özmantar, Bingölbali ve Akkoç, 2008; Erbaş, Çetinkaya ve Ersoy, 2009). Öğretimde hatalar ile hataların tespit edilmesi büyük önem taşımaktadır. Burada ilk yapılacak işlem, hataların ortaya çıkarılması ve daha sonra da oluşturulacak öğrenme deneyimleri ile bu hataları ortadan kaldırmaktır. Anlamlı bir öğretimin planlanmasında öğretmenin, öğrencilerinin zayıf ve güçlü yönlerini ortaya çıkararak bunlar hakkında bilgi sahibi olması gerekir (Stefanich ve Rokusek, 1992; Akt. Bozan ve Küçüközer, 2007). Ayrıca hataya doğru yaklaşım ve doğru çözüm önerisi öğretmen adaylarının konu alan bilgisinin yeterliliğinin tespitinde kullanılabilecek bileşenlerden biridir. Derinlemesine matematik alan bilgisinde de hatayı doğru tespit edip sebebini de doğru açıklamak gerekir (Konyalığlu, Özkaya ve Gedik, 2012).

Öğretmen ve öğretmen adayları, dikkatsizlik sonucu oluşabilecek sistematik olmayan yanlışları ve yine sistematik olarak karşılaşacakları kavram yanılgıları ve yanılgılar sonucu oluşabilecek sistematikleşen hataları iyi analiz edebilmelidirler (Shabanifar, 2013). Bu anlamda öğretmen ve öğretmen adayları öncelikle süreç içerisinde gerçekleşen kendi öğrenmeleri üzerindeki hataları fark etmelidir. Çünkü öğrenirken nerede hata yaptığının bilincinde olan öğretmen ya da öğretmen adayları, öğrencilerinin de hatalarını daha kolay tespit edebilir. Bireylerin kendi öğrenme süreçleri üzerine düşünerek neyi, niçin, nasıl yaptıklarını sorgulamalarının önemli olduğu göz önüne alındığında öğretmen adaylarının problem çözmeye yönelik farklı becerilerinin geliştirilmesi önemli görülmektedir (Baki, Aydın ve Özmen, 2012). Bu nedenle problem çözmede öğretmen adaylarına kendi öğrenme süreçleri üzerinde düşünecek, kendi öğrenmelerini değerlendirecek ortamlar hazırlanmalıdır.

\section{Literatüre taraması}

Problem çözmenin oldukça karışık bir aktivite olması, problem çözme süreçlerinin ve becerilerinin değerlendirilmesini zorlaştırmaktadır. Bu nedenle alan yazındaki çalışmalarda alternatif değerlendirme çeşitleri yer almaktadır. Bu değerlendirme çeşitleri arasında standart testler, öğrencilerle klinik mülakat, protokol analizi, kendini değerlendirme, öğrenci notları ve sınıf gözlemleri yer almaktadır (Karataş ve Güven, 2003). Kendini değerlendirme (öz değerlendirme) 2005-2006 eğitim-öğretim yılında uygulanmaya başlanan ilköğretim programlarında yer alan alternatif değerlendirme yöntemlerinin de içinde bulunmaktadır. (Uzun ve Yurdabakan, 2011). Ayrıca öz değerlendirme olarak kullanılan yenilikçi etkinlikler değerlendirmeye olan bakış açısını değiştirmeye yardım eder (Schulesser, 2010). Baykara (2011)'nın söylediği gibi bireylerin kendi güçlü ve zayıf yönlerini bilmeye ihtiyaçları vardır. Çünkü birey öğrenme sırasında kendisini gözlemleyerek, eleştirerek ve kontrol ederek süreci bilinçli bir biçimde yaşamalıdır (Yıldırım, 2010).

Öz değerlendirmede kişi kendi öğrenmesiyle ilgili sorunların farkındadır ve bu da aslında bir problem çözme becerisidir. Öz-değerlendirme, genellikle öğrencilerin öğrenme süreci içerisindeki aktif katılımını ölçmeye yönelik kullanılır (Üredi ve Üredi, 2007). Buna ilaveten öz değerlendirme öğrencinin özerklik kazanmasında, mevcut seçenekler içinde en iyisine karar verme becerisini elde etmesinde, kişisel değerlendirme becerisini geliştirmesinde önemli bir basamaktır (Reyhanlığlu, 2012). Ayrıca öz değerlendirme kişinin kendi performansını değerlendirilmesini içermektedir (Uzun, 2010). Öz değerlendirmenin öğrenciye kendi öğrenmesinin sorumluluğunu verdiği, kalıcı öğrenmeler sağladığı, etkili öğrenmede çok önemli bir etken olduğu bilindiği halde 
Kul, Ü., Çelik, S. (2015). Pre-service mathematics teachers' self-evaluation in mathematics related-problem solving and their solutions. International Journal of Social Sciences and Education Research, 1 (2), 399-410.

ülkemizde bu değerlendirme türü halen yeteri kadar uygulanmamaktadır. Öz değerlendirme uygulamalarının derslerde daha sık yapılmasının öğrenciler için daha faydalı olabileceği düşünülmektedir (a.g.e). Roe (2010) çalışmasında öğrenme sürecinin kalitesinin artırılması için öz değerlendirme yönteminin eğitimde yaygın olarak kullanılmasını tavsiye etmiştir. Bu bağlamda öz değerlendirme ilköğretim, ortaöğretim ve yükseköğretim derslerinde kullanılmalı ve kendi öğrenmesinin sorumluluğunu taşıyan bireyler yetiştirilmelidir. Öz değerlendirme, özellikle eğitim fakültesi gibi öğretmen yetiştiren kurumlarda öğrenmeyi öğrenen ve öğreten nitelikli öğretmenler yetiştirilmesi açısından önemlidir.

Öğretmen adayları, öğretme-öğrenme süreçlerinde, öğrencilerin kendi öğrenmelerini ve öğrenme yollarını açığa çıkaran özgün değerlendirme stratejilerine yer vermeli ve öğrencilerin kendi bilgi yapılarını nasıl oluşturduklarını ortaya koymalarını sağlayan süreç değerlendirmeleri yapmalıdırlar (Köksal ve Demirel, 2008). Akıllı (2007)'ya göre öz değerlendirme yönteminin öğretmen eğitimine katkısı adlı yaptığı çalışmada, bu yöntemlerin öğretmen adaylarının daha nitelikli yetiştirilmesinde ve öğretmenlik mesleğine ilişkin yetkinliklerinin geliştirilmesinde önemli bir rol oynadığ1 sonucuna varmıştır. Problem çözmede kendini değerlendirmeyle ilgili çalışma yapan Hunsader (2005), matematiksel problem çözmede öz değerlendirmenin cinsiyete göre farklılı̆̆ını araştırmıştır. Çalışmasının sonuçlarından biri, okuma kabiliyetinin öz değerlendirmede en güçlü etken olduğunu ancak matematik yeteneklerinde etkili olmadığ saptamıştır. Literatürde problem çözmeye yönelik ve öz değerlendirmeye yönelik ayrı ayrı pek çok çalışma bulunmaktadır. Ancak problem çözmede öz değerlendirme kapsamına dahil edilebilecek çalışma sayısı yok denilecek kadar azdır. Bu sebeple öz değerlendirmeyi problem çözmede kullanan bir araştırmaya ihtiyaç duyulmuştur. Araştırma problem çözmede hata/ eksiklerini fark eden ortaokul matematik öğretmen adaylarının hata/eksikliklerine yönelik öneri getirmesi açısından faydalıdır. Gelecekte öğrencilerine matematiği öğretecek olan matematik öğretmen adaylarının öz değerlendirme yaparak kendi öğrenmelerinin sorumluluğunu taşımalarına katkı sağlayacak olması nedeniyle de önemlidir.

\section{Yöntem}

$\mathrm{Bu}$ araştırma nitel araştırma yöntemlerinden durum çalışması deseninde tasarlamıştır. Durum çalışması nitel araştırmalarda çok yaygın kullanılan bir yaklaşımdır. Nitel durum çalışmasının en temel özelliği bir ya da birkaç durumun derinliğine araştırılmasıdır. Yani bir duruma ilişkin etkenler (ortamlar, bireyler, olaylar, süreçler, vb.) bütüncül bir yaklaşımla araştırılır ve ilgili durumu nasıl etkiledikleri ve ilgili durumdan nasıl etkilendikleri üzerine odaklanılır (Yıldırım ve Şimşek, 2008).

\section{1 Çalışma grubu}

Bu araştırmanın çalışma grubunu 2014- 2015 eğitim öğretim yılında Artvin Çoruh Üniversitesi Eğitim Fakültesi İlköğretim Matematik Öğretimi Programı'nda öğrenim gören 1. Sinıf ortaokul matematik öğretmen adayları oluşturmaktadır. Çalışmaya gönüllü toplam 30 kişi katılmıştır.

\subsection{Veri toplama aract}

Ortaokul matematik öğretmen adaylarının problem çözmede başarısızlıklarına yönelik kendilerini değerlendirmeleri ve bu duruma karşı çözüm önerileri sunmaları için genel başarı düzeyi 
Kul, Ü., Çelik, S. (2015). Matematik öğretmen adaylarının problem çözmede öz değerlendirmeleri ve problem çözmeye yönelik önerileri. International Journal of Social Sciences and Education Research, 1 (2), 399-410.

düşük bir ders seçilmiştir. Bu anlamda öğretmen adaylarının vize notlarına bakılarak soyut matematik dersinin çalışma kapsamında ele alınabileceği düşünülmüştür. Öğretmen adaylarının vize sınavında çıkan konu alanı kapsamında 6 soru hazırlanmıştır. Hazırlanan her bir soru kendi içinde 3 alt sorudan oluşmaktadır. Birinci kısmında varsa öğretmen adaylarının kendi eksik/hatalarını tespit etmeleri, ikinci kısmında bu hata/eksiklerini konu alanı kapsamında değerlendirmeleri, üçüncü kısmında ise problemin çözümüne yönelik kendilerini geliştirecek önerilerde bulunmaları istenmiştir.

\section{3 İslem süreci ve analiz}

Ortaokul matematik öğretmen adayları için hazırlanan görüşme formu yaklaşık 120 dakika süreyle uygulanmıştır. Öğretmen adaylarına vize sınavında konu alanı kapsamında sorulan sorular, araştırmacılar tarafından çözülmüştür. Birinci soru sınıf ortamında çözülüp görüşme formundaki 1. sorunun öğretmen adayları tarafından cevaplanması istenmiştir. Aynı şekilde diğer sorular da çözülüp hemen arakasından o soruya yönelik öğretmen adaylarından cevaplar istenmiştir. Araştırmanın verileri tematik analiz yoluyla değerlendirilmiştir. Tematik analizde araştırmacı, içinde tema ve örüntüler aramak için analitik tekniklere odaklanır ve tematik analizin en önemli yönlerinden biri verileri kodlamadır (Ersoy ve Yalçınoğlu, 2012). Buradan hareketle veriler 3 aşamada araştırmacılar tarafından değerlendirilmiştir. Birinci aşamada her soru tek tek ele alınarak oluşan temalar belirlenmiştir. Böylelikle sorularda oluşan hata/eksiklere sebep olan durumlar ve öneriler tespit edilmiştir. İkinci değerlendirmede ise öğretmen adaylarının görüşme formuna verdikleri cevaplar ayrı ayrı analiz edilmiştir. Son aşamada ise bu iki değerlendirmeyle ortaya çıkan temalar ve altında toplanan kodlar yazılmıştır. Ancak değerlendirmeler sırasında birkaç kodun farklı kategorilerin içinde de yer aldığı aşağıdaki örneklerde ifade edilmiştir.

\section{Bulgular}

Katılımcıların problem çözümlerindeki öz değerlendirmeleri sonucunda ortaya çıkan ve başarısızlıklarına en çok sebep olan durumları yansıtan bulgular şekil 1 de sunulmuştur.

Şekil 1. Katılımcıların problem çözümünde başarısızlıklarına sebep olan durumlar

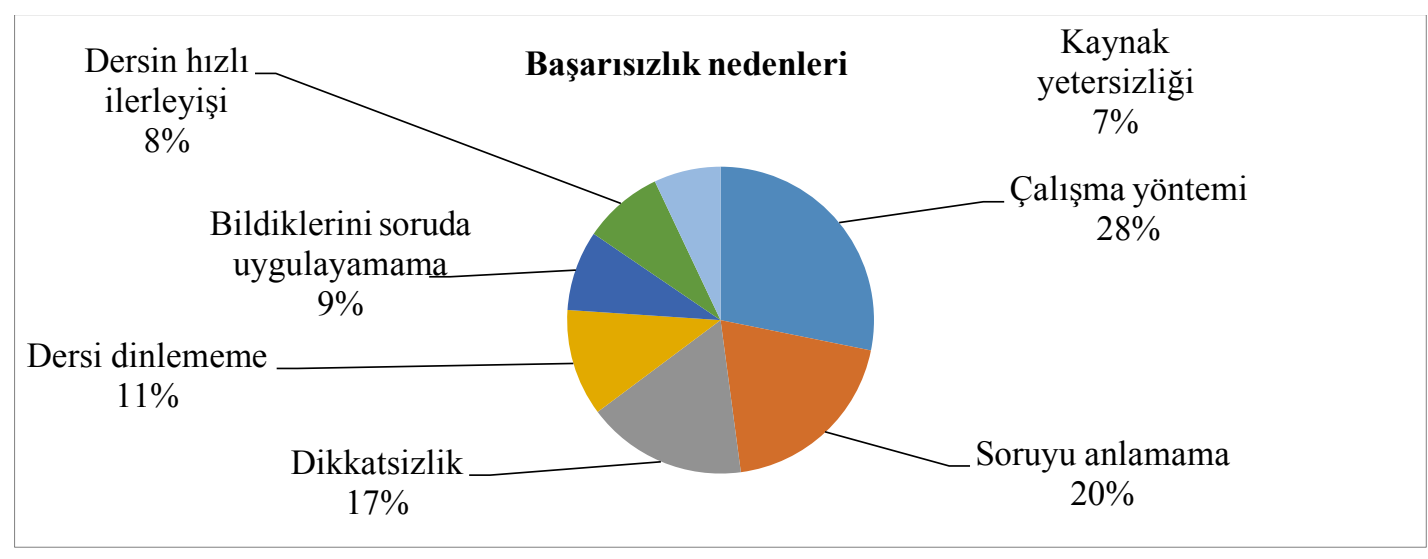

Katılımcılar, problem çözerken doğru cevaba ulaşamayıp düşük not almış olmalarını yukarıda gösterilen sebeplerle açıklamışlardır. Görüldüğü üzere katılımcılar, en önemli başarısızlık sebepleri olarak çalışma yöntemlerini (\%28), soruyu tam olarak anlamamış olmamalarını (\%20) ve dikkatsizliği (\%17) göstermiştir. Şekilde de görüldüğü gibi bu üç neden katılımcılara göre başa- 
Kul, Ü., Çelik, S. (2015). Pre-service mathematics teachers' self-evaluation in mathematics related-problem solving and their solutions. International Journal of Social Sciences and Education Research, 1 (2), 399-410.

rısızlık nedenlerinin büyük çoğunluğunu oluşturmaktadır. Ayrıca katılımcılara göre dersi dinlememe, problem çözmelerindeki başarısızlıklarında oldukça önemli bir etkendir. Katılımcılar dersi dinlemedikleri için konuyu derste öğrenemediklerini ve bu durumun başarısızlıklarında bir etken olduğunu ifade etmişlerdir. Bu nedenlerin dışında ayrıca bildiklerini soruda uygulayamama da bir diğer etken olmuştur. Katılımcılar problem çözmedeki başarısızlıklarında dersin hızlı ilerleyişi ve kaynak yetersizliğini kendileri dışında bir etmen olarak değerlendirmişlerdir. Katılımcıların problem çözümlerinde başarısızlığa neden olan durumlar ve bu durumlara karşı kendilerini geliştirecek çözüm önerilerini yansıtan bulgular Tablo 2 de sunulmuştur.

Tablo 1. Katılımcıların başarısızlık nedenleri ve çözüm önerileri

\begin{tabular}{|c|c|c|c|c|c|}
\hline \multicolumn{5}{|l|}{ Problemler } & \multirow[t]{2}{*}{ Öneriler } \\
\hline Kişisel & & & Çevresel & & \\
\hline Psikolojik & İşlem Becerisi & $\begin{array}{c}\text { Konu Alan } \\
\text { Eksikliği }\end{array}$ & Kurumsal & Diğer & $\begin{array}{l}\text { Matematiksel } \\
\text { dili geliştirme }\end{array}$ \\
\hline $\begin{array}{l}\text { Sinav kay- } \\
\text { gis1 }\end{array}$ & $\begin{array}{l}\text { İspat adımlarını } \\
\text { uygulayamama }\end{array}$ & $\begin{array}{l}\text { Matematiksel } \\
\text { dili kullana- } \\
\text { mama }\end{array}$ & $\begin{array}{l}\text { Kaynak ye- } \\
\text { tersizliği }\end{array}$ & $\begin{array}{l}\text { Derste az soru } \\
\text { çözümü }\end{array}$ & $\begin{array}{l}\text { Heyecan ve dik- } \\
\text { katsizlik sorunu } \\
\text { yenme }\end{array}$ \\
\hline $\begin{array}{ll}\text { Derse } & \text { karş1 } \\
\text { korku } & \end{array}$ & $\begin{array}{l}\text { İşlem ve ispatın } \\
\text { sonunu tamamla- } \\
\text { yamama }\end{array}$ & $\begin{array}{l}\text { Konuyu derste } \\
\text { anlamama }\end{array}$ & $\begin{array}{l}\text { Konu çok- } \\
\text { luğu }\end{array}$ & $\begin{array}{l}\text { Dersi derste } \\
\text { dinlememek }\end{array}$ & $\begin{array}{l}\text { Dersi iyi din- } \\
\text { leme }\end{array}$ \\
\hline $\begin{array}{lr}\text { İspat } & \text { kavra- } \\
\text { mina } & \text { ön- } \\
\text { yarg1 } & \\
\end{array}$ & $\begin{array}{l}\text { Bildiği kavram- } \\
\text { ları sınav anında } \\
\text { uygulayamama }\end{array}$ & $\begin{array}{l}\text { Yanlış çözüm } \\
\text { yolu uygulama }\end{array}$ & $\begin{array}{l}\text { Dersin hizlı } \\
\text { işlenişi }\end{array}$ & $\begin{array}{l}\text { Sinava farkl1 } \\
\text { nedenlerden } \\
\text { hazırlanamama } \\
\end{array}$ & $\begin{array}{l}\text { Kavramsal öğ- } \\
\text { renme }\end{array}$ \\
\hline Dikkatsizlik & $\begin{array}{l}\text { İspat yönteminin } \\
\text { uygulama şeklini } \\
\text { bilmeme }\end{array}$ & $\begin{array}{l}\text { Nasıl yapılaca- } \\
\text { ğını bilmeme }\end{array}$ & & & $\begin{array}{l}\text { Tekrar ve çok } \\
\text { çalışma }\end{array}$ \\
\hline $\begin{array}{l}\text { Öğrenilmiş } \\
\text { çaresizlik }\end{array}$ & & $\begin{array}{l}\text { Çözüm yolunu } \\
\text { hatırlayamama }\end{array}$ & & & $\begin{array}{l}\text { Motivasyon ar- } \\
\text { tırma }\end{array}$ \\
\hline
\end{tabular}

Katılımcılar problem çözümünde kendilerini değerlendirirken genel olarak kişisel ve çevresel başarısızlık nedenlerinin olduğu ortaya çıkmıştır. Kişisel nedenlerinin çevresel nedenlere göre daha çok olduğunu katılımcılar daha çok dile getirmiştir. Katılımcıların kendilerini değerlendirmede karşılaştı̆̆ kişisel nedenler psikolojik durum, konu alanı eksikliği ve işlem becerileriyle ilgili iken çevresel nedenler kurumsal ve diğer nedenler olarak ayrılmaktadır. Katılımcılar, çevresel nedenlerden biri olan derste az soru çözülmesi üzerinde diğerlerinden daha çok durarak temel sorunun bu olduğunu belirtmişlerdir. "Daha yavaş anlaşıllı ve bol örnekli anlatım daha iyi olabilir..." şeklindeki ifadeler ile katılımcılar kendilerini değerlendirirken çok soru çözmeleri gerektiğini ifade etmişlerdir. Çevresel nedenlerin içerisinde dikkat çeken bir diğer durum da katılımcıların, kaynak yetersizliğini başarısızlıklarının nedenleri arasında göstermeleridir. " Kendime soyut matematik soru bankası almam gerekiyor. Kütüphanedeki kaynaklar da yetersizdir... ”, ifadeleri bu görüşü destekler niteliktedir.

Psikolojik nedenlerden dikkatsizlik sorunu, problem çözümlerinde hatalara daha çok yol açmıştır. " Son gece hiç uyumadım. Bu yüzden dikkat eksikliğim çok fazlaydı...." şeklindeki açıklamalar katılımcıların dikkatsizlikten kaynaklanan sorununun problem çözümlerinde hatalara yol açtığını ifade etmişlerdir. Ayrıca katılımcıların derse karşı ön yargılarının da psikolojik nedenlerinden biri olduğu belirlenmiştir. Katılımcıların "Rakamlarla işlem yapllan matematiği geri istiyorum...", “Soyut matematikte yüksek alamamadaki asıl sebep dersin biraz karlşık olması. Mantığını ögrenmektense ezber yoluna gidiyorum bu da benim en büyük hatam..." ifadeleri bu görüşü destekler niteliktedir. Psikolojik nedenlerden biri olan sınav kaygısı da problem olarak 
Kul, Ü., Çelik, S. (2015). Matematik öğretmen adaylarının problem çözmede öz değerlendirmeleri ve problem çözmeye yönelik önerileri. International Journal of Social Sciences and Education Research, 1 (2), 399-410.

görülmektedir. " Sınavı yetiştiremeyeceğim diye heyecanlandım...' şeklindeki katılımcıların ifadesi ile kendilerini değerlendirmişlerdir. Bunun yanı sıra katılımcıların dersten kalma kaygılarının da olduğu belirlenmiştir. " Hepimizin dersten geçeceği garantisi verilirse güzel olur, kalmak korkusu olduğu için sinavda sorulara geniş açıdan bakamıyorum...'söylemleri ile katılımcılar dersten kalma kaygısı içinde olduklarını ve bu durumun problem çözümlerini etkilediğini ifade etmişlerdir.

Konu alanı eksikliğinin ve işlem becerisindeki eksikliklerin kendi içinde birbiriyle daha çok ilişskili olduğu görülmektedir (Şekil 2).

Şekil 2. Konu alanı eksikliği ve işlem becerisi eksikliği ilişkisi

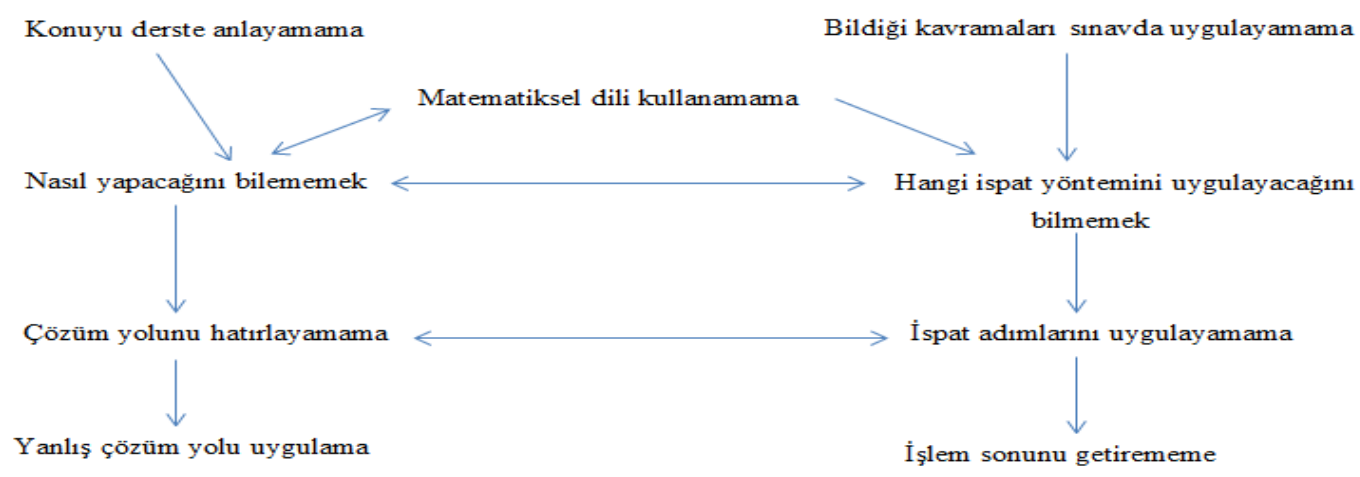

Katılımcılar konu alanı eksikliklerinin temel sebebi olarak konuyu derste anlamamalarının olduğunu ifade etmişlerdir. "Dersi derste anlamıyorum, anlamadığım için de çalı̧̧mak istemiyorum. " şeklindeki ifadeler ile katılımcılar kendilerini değerlendirmişlerdir.

Katılımcıların konu alanı eksikliği ile işlem becerilerinde ortak olan kod, matematiksel dili kullanamamalarıdır. "Değillerini yazarken $\{\exists x, \forall x, \in, \notin\}$ gibi ifadelerde niceleyicilerde yanlı̧ yapmış olabilirim ”, “ Aslında gidiş yolunu biliyorum ama aynı şeyleri yazınca bir yerde karıştırıyorum ... '’ifadeleri ile katılımcılar matematiksel dili tam kullanamadıklarını açıklamışlardır. Bu nedenle katılımcılar, problemleri nasıl çözeceklerini ve problem çözerken hangi yöntemi kullanacaklarına karar veremediklerini söyleyerek öz değerlendirmelerini yapmışlardır. " Semboller, işaretler çok karışık geliyor ... ", “'Bana göre bildiğimiz şeylerin matematik dili halini ögreniyoruz... ' Katılımcıların matematiksel dili yeterince kullanamamalarının, konu alanı eksikliğinin bir sonucu olan yanlış çözüm uygulamalarına ya da işlem becerisi eksikliğinin bir sonucu olan çözümün sonunu getirememelerine sebep olduğunu ifade etmişlerdir.

Katılımcılara göre şekil 1' de görülen işlem becerisi sorunlarının temel nedeni, bildikleri kavram ve özellikleri sınav sırasında kullanamamalarıdır. " Biri anlatıyor anliyorum ama uygulamaya geçemiyorum...”, “ Bazı özellikleri biliyorum ama soruya uygulayamadım.” katılımcılar bilinen özellikleri soruda uygulamadıklarını ifade ederek kendilerini değerlendirmişlerdir.

Katılımcıların problem çözümünde hangi yöntemin uygulanacağına karar verememeleri, ispat adımlarını uygulayamamalarına ve işlem sonunu getirememelerine sebep olmaktadır. 'Íspat yöntemlerini tam olarak anlamadım. Sonunu getiremiyorum." cümleleri bu görüşü destekler niteliktedir. 
Kul, Ü., Çelik, S. (2015). Pre-service mathematics teachers' self-evaluation in mathematics related-problem solving and their solutions. International Journal of Social Sciences and Education Research, 1 (2), 399-410.

Katılımc1lar problem çözümlerine yönelik öz değerlendirmelerinde doğru sonuca ulaşmak için önerilerde bulunmuştur. Daha etkili çalışmaları halinde soru çözümünde başarıyı artırabileceklerini düşünmektedirler. "Çalışmam lazım, üniversiteye gidersem ilk yll hep bilgisayara bakacağm diye kendime söz verdim. Kendime verdiğim sözü tutuyorum ama ondan taviz verip çalışmaya başlayacağım. "' şeklindeki açıklamalar bu görüşü destekler niteliktedir. Katılımcılar hem konu alanı eksikliğinde hem de işlem becerilerinde önemli bir etken olan matematiksel dili kullanamadıklarının farkındadırlar ve bu duruma yönelik olarak çözüm önerileri de getirmektedirler. “ $8 \mid\left(c^{2}-d^{2}\right) \quad \rightarrow$ işaretinin anlamının artık bildiğim için bir dahaki soruyu çözebilirim ... ”ş̧eklindeki açıklamadan katılımcıların matematik diline yönelik sembolleri bilmeleri gerektiği anlaşılmaktadır. Katılımcılar motivasyonlarını artırırlarsa soruları tam olarak yapabileceklerini düşünmektedirler. "Daha çok soru çözmek beni daha çok geliştirecektir. Yeterli motivasyonumu bulamadiğımı düşünüyorum. Kendimi motive edip hepsini yapabileceğimi düşünmeliyim... ' açıklaması bu görüşü destekler niteliktedir. Ayrıca katılımcıların ders çalışma yöntemlerinde kendilerine yönelik eleştiride bulundukları da görülmüştür. "Sinava çalışırken yanlış çalışma yöntemi kullandı̆̆ım için hata yaptım. Daha düzenli çalışsam daha iyi yazabilirdim... " şeklinde önerilerde bulunarak katılımcıların kendilerini değerlendirdikleri görülmüştür.

\section{Tartışma, sonuç ve öneriler}

Lisans düzeyindeki derslerde problem kurma etkinliklerine yönelik öğrenci yanıtlarında görülen hataların analizlerine yer verilmelidir. Nitel yaklaşımlar ile öğretmen adaylarının hatalara yönelik açıklamalarında, farklı hatalar sergilemelerine neden olan düşünce yapıları ortaya çıkabilir (Işık ve ark, 2012). Bu çalışmada da ortaokul matematik öğretmen adaylarının problem çözmede kendilerini değerlendirerek yaptıkları hataları fark etmeleri ve çözümlerine yönelik öneriler geliştirmeleri sağlanmıştır.

Ortaokul matematik öğretmen adayları problem çözmede kendilerini değerlendirirken birbirinden farklı hatalarla karşılaşmıştır. Çalışma bulgularında da yer aldığı gibi bazı öğretmen adaylarının matematiksel dili kullanamadıkları, bazılarının da ispat adımlarını uygulayamadıkları vb. farklı türden hatalar öğretmen adayları tarafından tespit edilmiştir. Bu durum da ortaokul öğretmen adaylarının matematiğe ilişkin zihinlerdeki şemaları hakkında bilgi vermektedir. Ayrıca öğretmen adaylarının hatalarını fark etmesi alan bilgisinin de yeterli olduğunu gösterir. Ancak bir kısım öğretmen adayı hata tespitinde yeterli alan bilgisine sahip değildir (Konyalığlu, Özkaya ve Gedik, 2012). Bu çalışmada ortaokul matematik öğretmen adayları hatalarını konu alanı kapsamında da değerlendirmişlerdir. Çalışma sonucuna göre öğretmen adaylarının özellikle önermeler ve ispat kavramı üzerinde eksikliklerinin olduğu ortaya çıkmıştır. Çalışmanın bu sonucu, Shabanifar (2013)'ın hata tespitinin öğretmenin matematik alan bilgisini şekillendirmede önemli bir yere sahip olduğu düşüncesi ile tutarlılık göstermiştir.

Ortaokul matematik öğretmen adayları problem çözmede yaptıkları hataların farkındadır. Öğretmen adaylarının problem çözmede konu alanı eksikliğiyle ve işlem becerisiyle ilgili öz değerlendirmeye yönelik hata tespitleri çoktur. Hatta bu iki etkenin birbiriyle iç içe karışık olarak öğretmen adayları tarafından dile getirildiği saptanmıştır. Ortaokul matematik öğretmen adaylarına göre konu alanı eksiliği ve işlem becerileri dışında problem çözmede kendilerinden kaynaklanmayan nedenlerin de olduğu ortaya çıkmıştır. Bunlar sınava (süresi, zamanı v.b. ), sorulara (kolay-zor), derse ve ders kaynaklarına ilişkin olarak açıklanabilir. 
Kul, Ü., Çelik, S. (2015). Matematik öğretmen adaylarının problem çözmede öz değerlendirmeleri ve problem çözmeye yönelik önerileri. International Journal of Social Sciences and Education Research, 1 (2), 399-410.

Her ne kadar bireyin kendisinden kaynaklanmayan faktörler problem çözme sürecine etki edebiliyor olsa da bireyin kendisinden gelen faktörlerin sürece daha çok etki ettiği görülmektedir (Yıldırım, 2010). Bu çalışma kapsamında da çevresel nedenlere göre kişisel nedenlerin problem çözmede daha etkili olduğu bulunmuştur. Ortaokul matematik öğretmen adayları, problem çözümündeki başarısızlıklarını çevresel sebeplerden çok kişisel sebeplere bağlamıştır. Çevresel nedenlerden genel olarak bahsederken, kişisel nedenlerden özellikle psikolojik nedenleri açıklayarak bu nedenlerin problem çözme sürecini nasıl etkilediğini açıklamışlardır. Ayrıca kişisel nedenlerden biri olan psikolojik neden, kişiye özgü olduğu için diğer nedenlere göre daha çok çeşitlilik göstermiştir.

Ortaokul matematik öğretmen adayları problem çözme süreçlerini değerlendirirken çözümlerindeki başarısızlıklarını, soyut matematik dersine de bağladıkları görülmüştür. Ortaokul matematik öğretmen adaylarının problem çözmede kendi hatalarını değerlendirmeleri için lisans döneminde diğer derslere göre başarısız oldukları ders olarak soyut matematik dersi bu çalışma için seçilmişti. Çalışmanın bulgularında da görüleceği üzere öğretmen adaylarına göre başarısızlığın sebeplerinden biri de soyut matematik dersinin kendisidir. yer aldığı gibi öğretmen adaylarının ifadelerinden problem çözmedeki başarısızlıkları soyut matematik dersinden de kaynaklandığı ortaya çıkmıştır.Soyut matematik adından da anlaşılabileceği gibi, sayısal işlemlere dayalı olmayan, sembollerle düşünme, irdeleme ve hipotezler öne sürme ve bunları matematiksel yöntemlerle kanıtlama becerileri gerektiren bir derstir. Öğrencilerden, alıştıklarının dışında, doğru sonucu en kısa sürede bulmaları değil, sonuca ulaşmak için bir yol oluşturmaları beklenmektedir. Başka bir deyişle yol sonuç kadar hatta bazen daha önemlidir. Ancak öğrencilerin sözü geçen kavramları 9. sınıftan itibaren sorgulayarak, araştırarak ve anlayarak edinmemeleri, üniversite düzeyine geldiklerinde bu dersten başarılı olmalarını engellemektedir (Moralı, Köroğlu ve Çelik, 2004).

Ortaokul matematik öğretmen adaylarının yaptıkları hatalardan yola çıkarak problem çözme sürecine yönelik geliştirdikleri öneriler verimli ders çalışma, motivasyon artırma, dikkatsizliğin üstesinden gelme vb. olarak sıralanabilir. Öğretmen adaylarının yaptıkları hatalardan yola çıkarak çözüm önerileri getirmesi bir sonraki problem çözümüne katkı sağlayacaktır. Bireyin çözüm sürecinde kendini planlaması izlemesi ve değerlendirmesi süreci olumlu yönde etkilemekte ve başarıyı artırmaktadır (Yıldırım, 2010). Eksikliklerinin farkında olan ve buna ilişkin çözüm önerisi getiren ortaokul matematik öğretmen adayları, gelecekteki öğrencilerinin de problem çözümündeki hataları fark edecektir. Örneğin bu çalışmada problem çözme sürecini etkileyen kaygı, önyargı, korkunun azaltılmasına yönelik öneriler ortaya çıkmıştır. Bu gibi psikolojik nedenlerin ve bunlara ilişkin çözüm önerilerinin farkında olan öğretmen adayları, öğrencilerine problem çözmede daha rahat bir ortam sağlayacaktır. Kendini yeterince tanıyan, neleri tam, neleri eksik yaptığını bilen öğretmen adayları, çalışma yaşamına başladıklarında daha az sorunla karşılaşacaklardır (Kumandaş ve Kutlu, 2013). Ayrıca birçok çalışmada öz-yönetimli (self-directed learning) ve öz-yansıtmalı öğrenmenin (self-reflective learning), öğrencilerin akademik ve bireysel gelişimleri üzerinde olumlu etki gösterdiği kanıtlanmıştır (Karaman, Şahin ve Durukan, 2014 ).

Ortaokul matematik öğretmen adaylarının problem çözmeye yönelik kendi hatalarını tespit etme ve hatalarına ilişkin çözüm önerileri getirdiği bu çalışma, nitel başka bir çalışma ile daha kapsamlı hale getirebilir. Yansıtıcı düşünmeyi de içeren, hataları değerlendiren ve çözüm önerisi getiren bir çalışma yapılabilir. Problem çözme süreci sonrası klinik mülakatlar da yapılarak derinlemesine daha fazla bilgi elde edilebilir. 
Kul, Ü., Çelik, S. (2015). Pre-service mathematics teachers' self-evaluation in mathematics related-problem solving and their solutions. International Journal of Social Sciences and Education Research, 1 (2), 399-410.

\section{Kaynakça}

Akıll1, M. (2007). Öz değerlendirme ve akran değerlendirmesi yöntemlerinin öğretmen eğitimine etkisi. Atatürk Üniversitesi, Fen Bilimleri Enstitüsü, Erzurum.

Baki, A., Aydın, G.F., Özmen, M.Z. (2012). İlköğretim Matematik Öğretmeni Adaylarının Problem Çözmeye Yönelik Yansıtıcı Düşünme Becerilerinin İncelenmesi. Uluslararası Ĕgitim Programları ve Ö̆gretim Çalı̧̧maları Dergisi, 2(3). 60-72.

Baykara, K. (2011). Öğretmen adaylarının bilişötesi öğrenme stratejileri ile öğretmen yeterlik algıları üzerine bir çalı̧̧ma. Hacettepe Üniversitesi Eğitim Fakültesi Dergisi (H. U. Journal of Education)40: 8092

Bozan, M.,Kü̧̈üközer, H. (2007). Elementary School Students' Errors in Solving Problems Related to Pressure Subjects.Illköğretim Online, 6(1), 24-34,

Ersoy, A.,Yalçınoğlu, P.(2012). Nitel araştırmaya giriş. Ankara: Anı Yayıncılık: ÇEVİRİ

Erbaş, K.A., Çetinkaya, B., Ersoy, Y.(2009). Öğrencilerin Basit Doğrusal Denklemlerin Çözümünde Karş1laştıkları Güçlükler ve Kavram Yanılgıları. Eğitim ve Bilim, 34, 152, 45-59.

Hunsader, P.D. (2005). Lessons Learned About Boys' andGirls' Mathematical Problem Solving: The Solution Processes, Performance, Linguistic Explanations, Self-Efficacy, and Self-Assessment of FifthGrade Students of Varying Reading and Mathematics. University of South Florida. Doctor of Philosophy.

Işık,C., Kar, T., Işık,A., Güler, G.(2012). İlköğretim Matematik Öğretmeni Adaylarının Kesirlerde Toplama İşlemine Yönelik Kurulan Problemlerdeki Hataları Belirleyebilme Becerileri. The Journal of Computer and Mathematics Education. 3 (3). 161-182.

Karaman, P., Şahin, Ç., Durukan, H.(2014).Üstbilişin Öğrenme, Öğretme ve Ölçme-Değerlendirme Aç1sından İncelenmesi. Uşak Üniversitesi Sosyal Bilimler Dergisi. 7/2.187-202.

Karataş, İ., Güven, B. (2003). Problem çözme Davranışlarının Değerlendirilmesinde Kullanılan Yöntemler: Klinik Mülakatın Potansiyeli. Illköğretim - Online 2(2), 2-9.

Konyalığlu, C.A., Özkaya, M., Gedik, D.S. (2012). Matematik Öğretmen Adaylarının Konu Alan Bilgilerinin Hataya Yaklaşımları Açısından İncelenmesi. Iğdır Üni. Fen Bilimleri Enst. Der. 2(2,Ek:A): 2732 ,

Köksal, N., Demirel, Ö.(2008). Yansıtıcı düşünmenin öğretmen adaylarının öğretmenlik uygulamalarına katkıları. Hacettepe Üniversitesi Eğitim Fakültesi Dergisi (H. U. Journal of Education)34: 189-203.

Kumandaş, H., Kutlu, Ö. (2013). Okulöncesi öğretmen adaylarının kendi sunum becerilerine ilişkin öz değerlendirmeleri ile eğitici değerlendirmesinin karşılaştırılması. Eğitim Bilimleri ve Uygulama, 12(23), 43-55.

Moralı, S., Köroğlu, H., Çelik, A. (2004). Buca Eğitim Fakültesi Matematik Öğretmen Adaylarının Soyut Matematik Dersine Yönelik Tutumları ve Rastlanan Kavram Yanılgıları. Gazi Eğitim Fakültesi Dergisi, 24(1). 161-175.

Özmantar, F.M., Bingölbali, E., Akkoç, H. (2008). Matematiksel Kavram Yanılgıları ve Çözüm Önerileri. Pegem Akademi, Ankara.

Reyhanlığlu, D.(2012). Öz değerlendirmeye dayal şans başarlsı düzeltmenin test ve madde istatistiklerine etkisi. Hacettepe Üniversitesi, Sosyal Bilimler Enstitüsü, Ankara.

Roe, W.J. (2010).Student self-assessmentandstudentratings of teacherrapport in secondarystudentcourseratings.Utahstateuniversity,Doctor of Philosophy, LoganUtah 
Kul, Ü., Çelik, S. (2015). Matematik öğretmen adaylarının problem çözmede öz değerlendirmeleri ve problem çözmeye yönelik önerileri. International Journal of Social Sciences and Education Research, 1 (2), 399-410.

Schuessler,.N.J.(2010). Self assessment as learning: finding the motivations and barriers for adopting the learning-oriented instructional design of student self assessment.CapellaUniversity, Doctor of Philosophy.

Shabanifar, S. (2013). Matematik Öğretmen ve Öğretmen Adaylarının Muhtemel Öğrenci Hatalarına Yaklaşımı. Iğdır Üni. Fen Bilimleri Enst. Der. 3(2): 43-48.

Uzun, A. (2010). Illköğretim 4 ve 7. sınıf öğrencilerinin öz değerlendirme uygulamalarına yönelik tutumları. Dokuz Eylül Üniversitesi, Eğitim Bilimleri Enstitüsü, İzmir.

Uzun, A.,Yurdabakan, İ. (2011). İlköğretim öğrencilerinin öz-değerlendirmeye yönelik tutumlarının incelenmesi. Mehmet Akif Ersoy Üniversitesi Ĕ̈itim Fakültesi Dergisi, 22, 51 - 69.

Üredi, I., Üredi, L. (2007).Öğrencilerin öz-düzenleme becerilerini geliştiren öğrenme ortamının oluşturulmas1. Edu 7, Vol 2., No 4.

Yıldırım,A., Şimşek, H. (2008). Sosyal bilimlerde nitel araştırma yöntemleri.Ankara: Seçkin Yayıncılık.

Yıldırım, S. (2010). Üniversite öğrencilerinin bilişötesi farkındalıkları ile benzer matematiksel problem türlerini çözmeleri arasındaki ilişki. Yüksek Lisans Tezi. Gaziosmanpaşa Üniversitesi, Sosyal Bilimler Enstitüsü,Tokat. 
Kul, Ü., Çelik, S. (2015). Pre-service mathematics teachers' self-evaluation in mathematics related-problem solving and their solutions. International Journal of Social Sciences and Education Research, 1 (2), 399-410.

\section{Extended abstract in English}

Purpose and Significance: This is an important study for primary school pre-service mathematics teachers who recognized their errors and misconceptions in problem solving activity, and they offered solutions and recommendations pertaining to the issue. It is also important for preservice teachers who will teach mathematics in their future classrooms to make self-assessment for mathematical problems since this will help them to contribute to take responsibility for their own learning. Therefore, the aim of the study is to understand the reasons behind errors and deficiencies in dealing with mathematics-related problem solving and pre-service teachers' recommendation to this issue.

Literature: Analysing thought process of students may help educators to organize mathematics teaching and learning activities. Moreover, students' errors and misconceptions during problem solving may give us clues about their mathematical knowledge and skills (Karataş and Güven, 2003). The first step is here to discover the mistakes and then eliminate these mistakes with new learning experiences. In the planning of a meaningful education, teachers should reveal students' strengths and weaknesses and therefore, need to know about them (Stefanich and Rokusek, 1992 cited in Bozan and Küçüközer, 2007). Right approach and right solutions to errors that can be used to determine pre-service teachers' content knowledge.

Within the scope of in-depth mathematical content knowledge, it is necessary to identify students' mathematical errors properly and then explain the reasons behind this truthfully (Konyalığlu, Özkaya and Gedik, 2012).Teachers become aware about where they made mistakes through their learning and this may lead to identify future students' errors easily. When considering the importance of questioning on individuals' thinking on their learning process about what, why and how they do, it is important to develop pre-service teachers' different skills related to problem solving (Baki, Aydın and Özmen, 2012). Complexity of nature of problem solving activity makes it difficult to assess and evaluate problem-solving process and skills. Therefore, studies in the literature included alternative types of assessment such as standardized tests, clinical interviews with students, protocol analysis, self-assessment, classroom observation and students' field notes (Karataş and Güven, 2003). Self-assessment could be considered as an alternative assessment approaches, was introduced in 2005-2005 academic year with new enacted curriculum (Uzun and Yurdabakan, 2011). Furthermore, an innovative activity was used as a self-assessment method that will help to change perspective about assessment (Schulesser, 2010).

Methodology: Case study approach which is the one of the qualitative research methods was used in this study. To achieve the above aim, this study consist of first year pre-service mathematics teachers who are enrolled in Artvin Coruh University Faculty of Education Mathematics Education Department in the 2014-2015 academic year. For the study itself, a group of 30 preservice teachers who volunteered to participate in this research. According to pre-service teachers' exam results, abstract mathematics lesson was selected for this study in order to assess their errors and misconceptions in problem-solving process by themselves and their suggestions to this issue since their overall success for this lesson is low. An open-ended question form including six questions was developed by the researchers of the study in order to collect required data. Each question consisted of three sub-questions dealing with pre-service teachers' evaluation about problem solving process. Interview forms with thirty primary mathematics teachers' candidate were applied and lasted at least 120 minutes. In the first part, pre-service teachers were requested to identify their errors and misconceptions, and in the second part, they evaluate their errors and 
Kul, Ü., Çelik, S. (2015). Matematik öğretmen adaylarının problem çözmede öz değerlendirmeleri ve problem çözmeye yönelik önerileri. International Journal of Social Sciences and Education Research, 1 (2), 399-410.

misconceptions in the light of content area and finally, they were asked to make suggestions for the solutions of mistakes so as to develop their skills. Data of the study were analysed through method of thematic analysis.

Results and Conclusion: According to participants' accounts, their errors and misconceptions in dealing with problem solving process that could be classified as having both personal and environmental issues was revealed through the qualitative analysis of the data. It was determined that personal issues are more effective than environmental issues. The results showed that the researchers classified the reasons behind participants' errors and deficiencies in dealing with mathematics-related problem solving as an either personal issues which are mainly related to psychological, lack of content knowledge and operational skills, and as an environmental issue which are related to institutional and other. It was found that participants offered some solutions and recommendations pertaining to the above issues were the methods and duration of teaching, familiarity of technical mathematical language and terms. This study presented some recommendations for the researchers who will study on this relevant field. 